\title{
Review Article \\ Structuring Effects of Deer in Boreal Forest Ecosystems
}

\author{
Steeve D. Côté, ${ }^{1}$ Julien Beguin, ${ }^{1}$ Sonia de Bellefeuille, ${ }^{1}$ Emilie Champagne, ${ }^{1}$ \\ Nelson Thiffault, ${ }^{1,2}$ and Jean-Pierre Tremblay ${ }^{1}$ \\ ${ }^{1}$ Chaire de Recherche Industrielle CRSNG en Aménagement Intégré des Ressources de Lîle d'Anticosti, \\ Département de Biologie et Centre d'Études Nordiques, Université Laval, Québec, QC, Canada G1V 0A6 \\ ${ }^{2}$ Direction de la Recherche Forestière, Ministère des Forêts, de la Faune et des Parcs, 2700 Einstein, Québec, QC, Canada G1P 3 W8
}

Correspondence should be addressed to Steeve D. Côté; steeve.cote@bio.ulaval.ca

Received 2 June 2014; Accepted 19 August 2014; Published 16 September 2014

Academic Editor: Junbao Yu

Copyright (C) 2014 Steeve D. Côté et al. This is an open access article distributed under the Creative Commons Attribution License, which permits unrestricted use, distribution, and reproduction in any medium, provided the original work is properly cited.

\begin{abstract}
Many deer populations have recently increased worldwide leading to strong direct and indirect ecological and socioeconomical impacts on the composition, dynamic, and functions of forest ecosystems. Deer directly modify the composition and structure of vegetation communities, but they also indirectly affect other species of the ecosystem by modifying the structure of the vegetation. Here we review the results of a research program on overabundant white-tailed deer (Odocoileus virginianus) in the boreal forest of Anticosti Island (Québec, Canada) aimed at identifying deer densities compatible with forest regeneration. Various silvicultural systems and treatments failed to regenerate deer habitat at high deer densities, but planting size-adapted seedlings could be effective at moderate densities. Using a controlled deer density experiment, we found vegetation recovery at deer densities $\leq 15 \mathrm{deer} / \mathrm{km}^{2}$. The same experiment revealed that other groups of organisms such as insects and birds responded favorably to a reduction of deer density. We also found that alternative successional trajectories may occur after a certain period of heavy browsing during early succession. We conclude that one of the most important remaining research gaps is the need to identify habitat-specific threshold densities at which deer impacts occur and then to design effective wildlife and forest management strategies to limit deer impacts and sustain ecosystem integrity.
\end{abstract}

\section{Introduction}

Several populations of cervids (hereafter deer) have increased worldwide during the last decades causing strong direct and indirect ecological and socioeconomical impacts on the composition, dynamic, and functions of forest ecosystems [1]. In North America, white-tailed deer (Odocoileus virginianus, Zimmermann) has become overabundant in several regions $[2,3]$, forcing wildlife and forest managers to develop new ways of managing deer-forest systems. This review summarizes the results of a research program on Anticosti Island (Québec, Canada) that exemplified how an overabundant white-tailed deer population modified a boreal forest ecosystem. We also address how a careful assessment of changes in the ecosystem provides valuable science-based guidelines for the development of innovative and integrated wildlife and forest management strategies.

Heavy browsing caused by high deer densities directly impacts plant communities and tree regeneration dynamics
(Figure 1). These impacts often lead to dominance of plant species tolerant to browsing into communities [4], lower abundance or extirpation of less tolerant species [5-7], and changes in compositional and functional patterns of plant diversity [8-10], possibly reducing the productivity of ecosystems $[11,12]$. Deer can also modify soil dynamics and vegetation by trampling and nutrient deposition via their feces, urine, and carcass [13, 14]. Moreover, heavy browsing often induces additional silvicultural costs by preventing the establishment and height growth of palatable tree species [15, 16]. When the magnitude of impacts caused by deer on vegetation overcomes the resilience of forest ecosystems (sensu [17]), deer browsing can further alter trajectories of forest succession $[15,18]$ or possibly yield alternative stable states [6]. The last two decades of research have greatly improved our understanding of the role played by deer browsing on changes in vegetation patterns and dynamics. Less is known, however, about how the changes in patterns of primary producers 


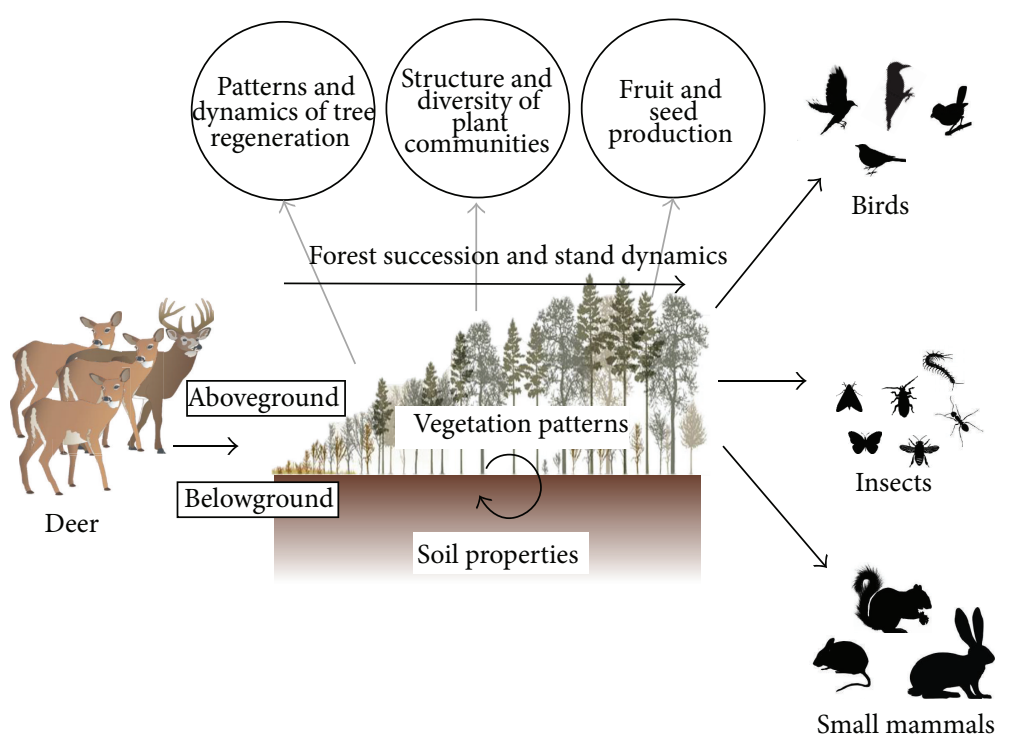

FIGURE 1: Direct and indirect effects of deer overabundance on forest succession and other species in the ecosystem.

indirectly impact assemblages of animal species at different trophic levels (Figure 1). For instance, overabundant deer populations may limit the availability of plant species to other primary consumers (i.e., insects, birds, and small mammals) that directly depend on browsing intolerant plant species as a main source of forage, hiding cover, or for reproduction needs [19-22]. In turn, the lower abundance of primary consumers might initiate trophic ricochets (sensu [23]) on predators, carnivores, and decomposers altering the structure and interactions among the entire food web [24-27].

To answer these questions, we have launched a long-term multidisciplinary research program on deer-boreal forest relationships [28]. We first experimented different types of large cutblocks to regenerate deer habitat; then we applied a series of controlled and replicated experiments at large spatial scales to identify deer density thresholds compatible with forest regeneration. In particular, we have established a controlled deer density experiment to investigate the response of several ecosystem components (e.g., soil properties, vegetation, insects, birds, and small mammals) along a gradient of deer browsing intensity.

\section{Context}

Anticosti Island $\left(7943 \mathrm{~km}^{2}\right)$ is located in the Gulf of St. Lawrence in Québec, Canada $\left(49^{\circ} 28^{\prime} \mathrm{N}-63^{\circ} 00 \mathrm{~W}\right.$; Figure 2). The forest ecosystem belongs to the eastern balsam fir (Abies balsamea) - white birch (Betula papyrifera) bioclimatic subdomain [29]. The preindustrial forest was characterized by a matrix of overmature softwood stands dominated by balsam fir with the inclusion of younger stands [30]. Stand regeneration is typically supported by banks of shade-tolerant balsam fir seedlings capable of reestablishing canopy dominance following a disturbance (advance regeneration [31]).

Approximately 200 white-tailed deer were introduced on Anticosti Island at the end of the 19th century, and they rapidly multiplied, taking advantage of a suitable habitat in the absence of predators. The deer population now reaches a density $>20$ deer $/ \mathrm{km}^{2}$ locally [32] and appears mainly limited by the availability of winter food resources [33], fluctuating annually according to winter severity [34].

Such a high deer density had strong repercussions on the forest. Major modifications in the woody and herbaceous vegetation layers related to intense deer browsing have been reported, such as the quasi-disappearance of the shrub layer and of most deciduous species [35-37]. The regeneration of balsam fir forests, a key habitat for deer winter survival on Anticosti Island [38], is currently compromised by deer browsing on balsam fir seedlings. Balsam fir stands are being progressively replaced by the less palatable white spruce (Picea glauca) through apparent competition $[35,39,40]$. In addition, despite the infrastructures and facilities in place today, sport hunting removes less than $5 \%$ of the total population annually, a harvest insufficient to achieve population control [34, 41].

A forest management program was established on the island in 1995 to favor balsam fir regeneration, thus allowing the reestablishment of balsam fir stands. The core of the integrated forest management strategy is based on fencing of large cutover areas $\left(\sim 7-10 \mathrm{~km}^{2}\right)$ comprising clear-cuts and residual forests [42] (Figure 2). Deer density within fenced areas is greatly reduced by sport hunting. Clear-cuts emulate natural disturbances resetting the regeneration dynamics of balsam fir forests by releasing the understory advance regeneration. When the stocking of balsam fir seedlings is deficient, the plan provides for plantation of nursery grown balsam fir seedlings. Once fir saplings will be high enough to escape browsing (up to 15 years), the fences will be removed. The residual forest stands act as winter cover interspersed with forage patches providing adequate deer habitat [43]. Managers were also concerned by the potential negative effects on other plant or animal species associated with the disappearance of balsam fir forests. In addition, they feared 


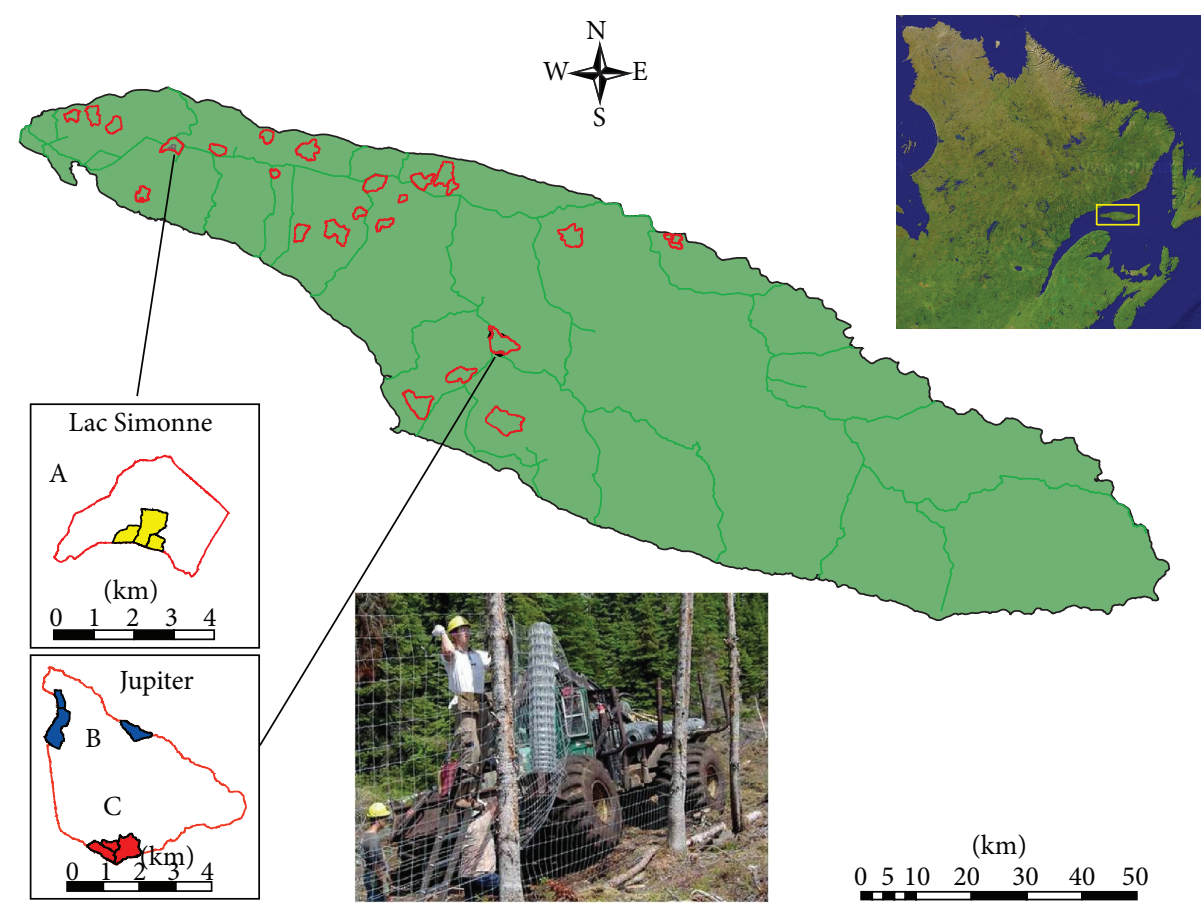

FIGURE 2: Location of the large management enclosures $(n=26)$ and the controlled browsing experimental sites on Anticosti Island, Québec, Canada.

that deer hunting, the main economic activity on the island, might be negatively affected [42]. To address the complex relationships between deer, forests, and the exploitation of natural resources in the boreal forest, the Industrial Research Chair in Integrated Resource Management of Anticosti Island was created at Université Laval (Québec, Canada) in 2001.

The first objective of the Chair Research Program is to develop forest and wildlife management approaches adapted to high deer densities. The four main research themes cover fundamental and applied aspects related to the sustainable development of resources and include the relationships between high deer densities and ecological processes of forest ecosystems, the habitat selection and foraging behavior of white-tailed deer, the development of silvicultural strategies compatible with high herbivore densities, and the definition and development of integrated tools to manage biological forest resources exposed to high deer densities [28].

\section{Research on Anticosti}

3.1. Testing Silvicultural Systems and Treatments. A key element of our research program is the use of in situ largescale factorial experiments to unravel how local deer densities and habitat characteristics influence deer impacts on tree regeneration success. Our first set of experiments specifically challenged the "habitat characteristics" hypothesis, which states that the susceptibility of tree regeneration to deer browsing depends on the surrounding biotic and abiotic conditions prevailing at microsite, stand, and landscape scales [44]. This hypothesis predicts lower impacts of deer on tree regeneration at longer distances to forest edges within cutblocks, as a result of higher predation risk perceived by deer with increasing distance from escape cover [45].

We tested this prediction in large clear-cut blocks using replicated pairwise fenced and unfenced plots located at various distances from the forest edge. Results demonstrated that, in absence of natural predators, the magnitude of deer impacts on palatable tree regeneration was independent of distance from escape cover [46]. In a second set of experiments, we tested whether the susceptibility of tree regeneration to deer browsing depended on silvicultural systems [44]. We expected tree regeneration under a "closeto-nature" silvicultural system (e.g., shelterwood and natural regeneration) to create abundant regeneration via increased seed supply of several species and allow balsam fir seedlings to develop beyond the reach of deer $[47,48]$. We experimentally tested this prediction under in situ deer densities $\left(\geq 15\right.$ deer $\left./ \mathrm{km}^{2}\right)$ using a broad range of silvicultural systems, including shelterwood cutting of various intensities $(0,25$, or $40 \%$ removal of the stand basal area), strip clear-cutting (strip width of 15,30 , or $45 \mathrm{~m}$ ), group seed-tree cutting with a gradient of scarification intensity, and large clear-cuts [49, 50]. Overall, deer browsing in natural conditions prevented the growth in height of all palatable tree seedlings in every silvicultural system, even when seedling density was locally high $[49,50]$. Finally, using planted balsam fir seedlings of various sizes, we tested the "apparency" theory, which states that herbivores are most likely to feed on plants that are easier to find [51]. We hypothesized that, under low to medium deer densities, seedlings that are either taller or grow faster than the average are more susceptible to browsing than others [52]. Indeed, we showed that, for seedlings planted in clear-cut 


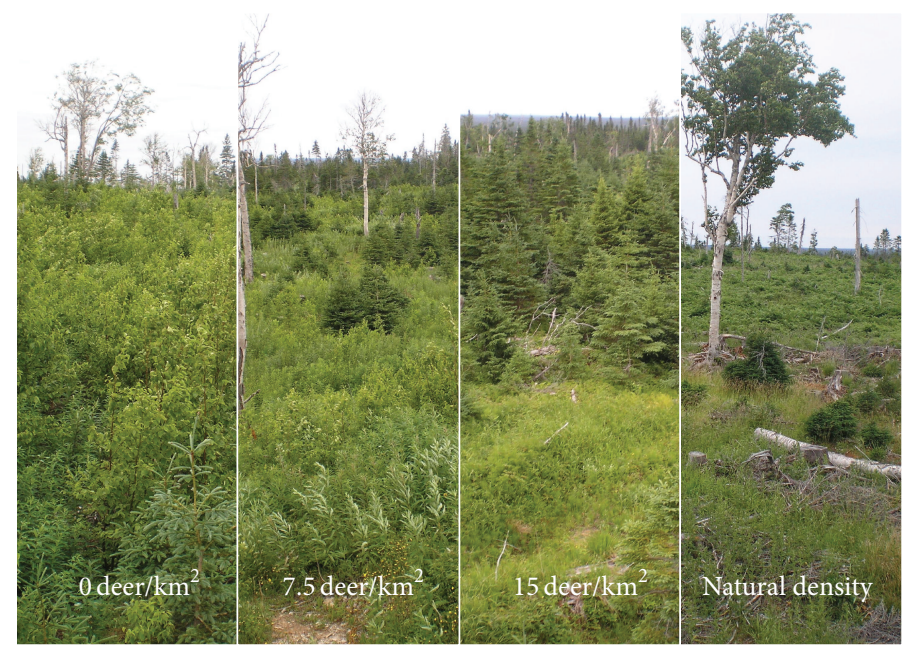

Figure 3: Vegetation after 7 years of the controlled browsing experiment in the boreal forest of Anticosti Island, Québec, Canada (photos by E. Cardinal).

areas, the relative risk of being browsed increases with seedlings height at the end of the previous growing season [53].

Lessons can be drawn from these early studies. First, food-dependent and -independent factors controlled by silvicultural systems, such as distance to stand edge, local seedling density, species planted, amount of woody debris, and size of opening areas, play no significant roles in mitigating browsing impacts on natural regeneration when deer population densities are $\geq 15$ deer $/ \mathrm{km}^{2}[35,46,49,50]$. Second, when deer densities are between 10 and 15 deer $/ \mathrm{km}^{2}$, there is a prominent bottom-up control of planted seedlings during early growth by interspecific competition instead of a top-down control by deer, which implies that the use of size-adapted stock could optimize the restoration scheme following deer population reduction [53]. However, the longterm evaluation of plantation success is required to confirm this suggestion because seedling growth over time increases their browsing probability. Overall, these studies highlight the critical role of high deer densities in the magnitude of browsing impacts on tree regeneration.

\subsection{Estimating Deer Density Compatible with Natural Succes-} sional Processes. A recurrent theme in deer-forest literature is the dearth of studies addressing threshold deer densities compatible with the maintenance of natural processes in forests [1]. Progress in understanding how ungulates modify ecosystems, both directly and indirectly, and respond to ecosystem changes requires controlled factorial experiments that manipulate deer density and other factors interacting to influence forest dynamics, especially natural and man-made perturbation regimes [54-57]. We embraced this challenge using a controlled browsing experiment that manipulated both deer densities $\left(0,7.5,15 \mathrm{deer} / \mathrm{km}^{2}\right.$ and in situ density up to $56 \mathrm{deer} / \mathrm{km}^{2}$ ) and forest structure (clear-cut and uncut forest) during 8 consecutive years (2002-2009). Deer densities and vegetation cover types were replicated in 3 blocks, with 4 experimental units per block (Figure 2). The fenced experimental units were dominated by balsam fir $(>70 \%$ canopy cover) before the beginning of the experiment. In each block, we maintained a deer-free 10 ha exclosure, 3 deer in a 40 ha enclosure made of 3-meter-high wire game fence ( $\left.7.5 \mathrm{deer} / \mathrm{km}^{2}\right)$, and 3 more in a 20 ha enclosure $\left(15 \mathrm{deer} / \mathrm{km}^{2}\right)$. We controlled deer density by relocating 3 deer per enclosure each spring and culling them in late autumn. We monitored in situ deer densities in unfenced sites located near the enclosures using distance sampling of summer feces (see [58] for details).

The response of the ground layer vegetation in the early succession phase following forest harvesting revealed a fast recovery rate of compositional, reproductive, and morphological attributes of plants at densities below $15 \mathrm{deer} / \mathrm{km}^{2}$ and suppression of growth or reproduction at higher densities [58] (Figure 3). Browse tolerant species, such as grasses, were positively related to deer density through exponential growth functions [58]. Such field layer can be hard to penetrate for woody species and has therefore been termed a recalcitrant understory [59]. Sexual reproduction of commonly grazed species, such as Anaphalis margaritacea, Aster spp., Cerastium vulgare, Clintonia borealis, Conioselinum chinense, Chamerion angustifolium, Geum macrophyllum, Gnaphalium uliginosum, Hieracium spp., Mä̈anthemum canadense, Petasites spp., Prenanthes spp., Ranunculus acris, Senecio spp., Streptopus roseus, Rubus idaeus, Rubus spp., Taraxacum officinale, Trientalis borealis, and Vaccinium spp., was inhibited by herbivory at local density levels exceeding $15 \mathrm{deer} / \mathrm{km}^{2}$ but recovered exponentially at lower densities [58]. Six years after forest harvest and deer density control, plants associated with high deer density had functional traits such as asexual reproduction, abiotic pollination, and gravity/wind seed dispersal, while traits favored at reduced deer density included fleshy fruits, large seeds, and erected foliage [60].

In the first 3 years following timber harvesting and controlled browsing, the mortality of individually tagged balsam fir seedlings (height $<30 \mathrm{~cm}$ ) decreased exponentially 
with decreasing deer density in clear-cuts [40]. Mortality of seedlings at deer densities under $15 \mathrm{deer} / \mathrm{km}^{2}$ decreased over time and with age and stem height, converging eventually towards the mortality rate observed in exclosures with no deer [61]. Independently of deer density, percentage of plots with at least one recruit in clear-cuts dropped from $56 \pm 5 \%$ to $7 \pm 1 \%$ within 3 years [61]. The height of seedlings also increased exponentially with decreasing deer density in clearcuts after 3 years of control [61]. We observed almost no regeneration into the sapling stage $(>30 \mathrm{~cm})$ under in situ deer densities after 7 years [61]. Overall, the abundance of fir saplings recovered exponentially in clear-cuts but remained low and independent of deer density in uncut forest while the abundance of spruce Picea spp. saplings was unrelated to deer density and increased with time. Although we measured a relatively high stem density of balsam fir saplings 7 years after the start of the treatment, their ultimate contribution to the canopy remains to be confirmed.

The early responses of the ground layer and advance regeneration can shape succession processes as they determined the initial floristic composition and the competitive interactions between dominant species. Changes imposed by deer browsing at this stage may determine successive colonization events with long-term legacy effects, eventually leading to alternative successional trajectories (AST sensu [62]). Legacy effects are defined as indirect effects persisting for a long time in the absence of the causal species activities (sensu [63]). Legacy effects of deer browsing have been reported a long time after localized deer exclusion $[23,64,65]$, while other systems appear resilient to prolonged periods of heavy browsing pressure [66]. A conclusive experimental test of AST requires assessing whether a successional trajectory initiated under deer herbivory could be reversed. To this end, we implemented a delayed herbivore removal experiment; for a period of 15 years, we compared the composition and structure of the forest community in (1) original exclosures protecting regeneration from deer browsing directly after logging, (2) control plots, and (3) delayed exclosures that were built 8 years after logging on plots previously accessible to deer [18]. Although the palatable paper birch and some palatable herbs recovered in delayed exclosures, we observed legacies from trees and herbs resistant to browsing (sensu [67]). Woody regeneration in delayed exclosures was dominated by white spruce, while Poaceae (grasses) were abundant in the field layer [18]. We concluded that AST might occur after a limited period of heavy browsing during early succession because only early successional species managed to establish in exclosures constructed 8 years after logging, whereas late successional broadleaves and balsam fir remained rare. We suggest that, by acting as a chronic disturbance agent, deer can undermine the resilience of balsam fir forests and make them more vulnerable to AST.

3.3. Managing White-Tailed Deer Density. Hunting is the main management tool available to control deer populations [1]. To improve deer management using sport hunting, we studied the environmental variables that limit the efficiency of hunting. Using an innovative approach of monitoring the behavior of hunters with GPS technology, we found that the spatial distribution of harvested deer at different scales was mainly determined by the presence of access roads in open stands [68]. The abundance of deer forage also influenced the spatial distribution of harvested deer across the landscape, but to a lesser extent (see also [69]). Thus, habitat characteristics could be modified to increase deer harvest by improving accessibility and visibility near roads, for instance, by the creation of forest openings.

Intensive and localized harvest of antlerless deer has been proposed as another potential measure to reduce deer density [70]. The philopatric behavior of females is expected to limit recolonization of hunted zones [70,71]. To test the efficiency of this method under natural conditions, we monitored deer density, vegetation abundances, and growth as well as deer life-history traits during 6 years in five $20 \mathrm{~km}^{2}$ experimental sites where harvest rate of antlerless deer was increased by 30 to $50 \%$ and in 5 control sites where harvest rate was $5-7 \%$ [72]. Contrary to our expectations, deer density, vegetation abundance, and deer life-history traits did not differ in experimental and control sites [72]. Given the large efforts required for localized management, we conclude that the local control of overabundant deer populations through sport hunting may be difficult to achieve in areas where hunting pressure is limited.

\subsection{Assessing the Direct and Indirect Impacts of Deer on Other} Species. Intense browsing by abundant large herbivores can threaten the ecological integrity of ecosystems by inducing modifications in the structure and composition of vegetation that affect other animal communities [1, 20, 21, 73-76]. Using our large controlled browsing experiment, we investigated the relationships between deer density and different animal communities and species, including songbirds, insects, and small mammals.

3.4.1. Songbirds. Compared to the vegetation, the magnitude of the positive effects of the reduction in deer density on songbirds was limited. Nevertheless, 6 years of reduced deer density increased songbird richness and diversity [77]. Higher birch ground cover at reduced deer densities $\left(\leq 7.5 \mathrm{deer} / \mathrm{km}^{2}\right)$ increased the total abundance, species richness, and diversity of songbirds by $30 \%$ on average. The regeneration of white spruce at high deer density maintained many shrubdependent songbirds associated with forest canopy [77]. Overall, simplification of the vegetation structure by deer browsing homogenized the composition of songbird communities [78].

3.4.2. Insects. The sensitivity of insect taxa and feeding guilds to deer density decreased along a gradient representing their degree of association with plants [79]. The abundance of epigeal Carabidae, which do not have any direct relationship with plants, was independent of deer density. Macro Lepidoptera, however, a group intimately linked to vegetation, had higher species richness and a greater abundance of individuals from rare species at reduced than at in situ deer densities [79]. The reduction of deer density to $\leq 15$ deer $/ \mathrm{km}^{2}$ might be sufficient to restore insect diversity on Anticosti Island. 
3.4.3. Small Mammals. Finally, we assessed the influence of deer density and forest harvesting on deer mice (Peromyscus maniculatus), the only small mammal species present on Anticosti Island [80]. We found higher mice abundance in clear-cuts than in intact adjacent forests, regardless of deer density. Our findings suggest that the indirect effects of deer browsing on generalist species such as deer mouse may be weak, possibly due to their omnivorous feeding habits. The interspecific relationships between deer and mice thus appear neutral in this system.

\section{Outlook}

Because the ecological and socioeconomical impacts of overabundant deer are expected to further increase in the near future, a number of research questions need to be addressed. One of the most important remaining research gaps is the identification of habitat-specific threshold densities at which deer impacts occur $[1,22,54,81]$. This would allow designing effective strategies to limit deer impacts and sustain ecosystem integrity. In addition, many factors have been treated separately in the study of deer-forest relationships, but we need to understand the interacting factors affecting ecosystem resilience [1]. For example, we must build from previous studies and further investigate the interactive effects of deer browsing pressure and other natural or anthropogenic disturbances $[65,82,83]$. The impacts of deer overabundance may be linear but most likely involve thresholds and nonlinear relations that should be included in research designs $[1,6,84]$. We must determine the recovery duration of ecosystems once deer density has been reduced $[22,58]$. We also need to assess the impact of plant-plant associations on the browsing risk, that is, the effect of the presence of companion species on accentuating or decreasing the risk of browsing on a particular (preferred) plant species (namely, associative susceptibility and associative resistance [85-87]). Although we have made large progresses to address the impact of deer density on biodiversity (e.g., $[77,79,88]$ ) since we outlined this gap as a research priority a decade ago [1], there is still a need to assess the effects of high deer density on the structure of ecosystems, and hence biodiversity.

Generally, we need more experiments of controlled large herbivore densities in several types of ecosystems $[8,54-$ $57,89,90]$. To date, only boreal forest (our work on Anticosti, e.g., [58, 91] for Alces alces) and temperate forest ecosystems $[92,93]$ have seen experiments at controlled deer density. For instance, there is a lack of studies about the impacts of high browsing pressure in tropical and subtropical environments, as well as in Arctic ecosystems where cases of cariboureindeer (Rangifer tarandus) overgrazing have been reported [94-96]. These studies would be particularly relevant for species such as lichens that take a long time to regenerate [97]. In addition, research on interactions between species in environments where a suite of large herbivore species coexist (e.g., Western Europe, New Zealand) is needed. For instance, the combined effects of sympatric herbivore species on ecosystems are not well known, except perhaps in African savannas $[98,99]$. We now know that deer browsing has the potential to lead to alternate successional trajectories [18], but we still need to determine whether positive retroaction induced by deer browsing can maintain forest ecosystems into alternate stable states or regimes on large spatial and temporal scales $[6,62,81]$.

From a forestry perspective, there is a need to further investigate the interacting impacts of regeneration density, seedling origin (natural versus planted), competing vegetation characteristics (composition, cover, and relative height), and deer density on stand regeneration success under high browsing pressure. Furthermore, these interactions should be studied within a range of silvicultural treatments such as precommercial and commercial thinning or shelterwood cutting $[53,100,101]$. We should determine how browsing pressure influences tree growth on sites of various fertilities in order to include the effect of deer in the estimation of timber harvest levels. Moreover, the sole and interacting effects of stock type characteristics, time since planting, soil and slash manipulation, and vegetation control [102104] must be integrated within a comprehensive model of stand management to guide silviculture. Within species, individual seedlings differ genetically in their susceptibility to browsing [105-108], suggesting that selection for species, varieties, and genotypes more resistant to browsing could be possible.

More locally, on Anticosti Island, the most crucial need remains to test the efficiency of large-scale fenced areas at reduced deer density to regenerate forests [42]. When vegetation height will be judged sufficient for trees to escape deer browsing, the fences will be removed [42]. The first enclosures are now approaching this state and thus, both the responses of plants (see above) and animals to the removal of the fences need to be measured. We need to assess how the removal of the fence will impact the space use of surrounding deer because it will increase the local abundance of forage and may thus attract deer over long distances.

\section{Conflict of Interests}

The authors declare that there is no conflict of interests regarding the publication of this paper.

\section{Acknowledgments}

The authors' research on white-tailed deer has been funded by the Natural Sciences and Engineering Research Council of Canada (NSERC), Produits Forestiers Anticosti, Université Laval, SÉPAQ Anticosti, Pétrolia, Safari Anticosti, and the Ministère des Forêts, de la Faune et des Parcs du Québec. The authors thank J. Huot for his pivotal role in establishing their research program on Anticosti Island and the community of Port-Menier for continuous support. The authors are grateful to all the graduate students, technicians, and field assistants for their involvement and work on the research program on Anticosti over the years. 


\section{References}

[1] S. D. Côté, T. P. Rooney, J.-P. Tremblay, C. Dussault, and D. M. Waller, "Ecological impacts of deer overabundance," Annual Review of Ecology, Evolution, and Systematics, vol. 35, pp. 113147, 2004.

[2] M. R. Conover, "Monetary and intangible valuation of deer in the United States," Wildlife Society Bulletin, vol. 25, no. 2, pp. 298-305, 1997.

[3] W. J. McShea, H. B. Underwood, and J. H. Rappole, Eds., The Science of Overabundance: Deer Ecology and Population Management, Smithsonian Institute Press, Washington, DC, USA, 1997.

[4] R. Perea, M. Girardello, and A. San Miguel, "Big game or big loss? High deer densities are threatening woody plant diversity and vegetation dynamics," Biodiversity and Conservation, vol. 23, no. 5, pp. 1303-1318, 2014.

[5] S. B. Horsley and D. A. Marquis, "Interference by weeds and deer with Allegheny hardwood reproduction," Canadian Journal of Forest Research, vol. 13, no. 1, pp. 61-69, 1983.

[6] D. J. Augustine, L. E. Frelich, and P. A. Jordan, "Evidence for two alternate stable states in an ungulate grazing system," Ecological Applications, vol. 8, no. 4, pp. 1260-1269, 1998.

[7] J. B. McGraw and M. A. Furedi, "Deer browsing and population viability of a forest understory plant," Science, vol. 307, no. 5711, pp. 920-922, 2005.

[8] N. T. Hobbs, "Modification of ecosystems by ungulates," Journal of Wildlife Management, vol. 60, no. 4, pp. 695-713, 1996.

[9] T. P. Rooney, R. J. McCormick, S. L. Solheim, and D. M. Waller, "Regional variation in recruitment of hemlock seedlings and saplings in the upper Great Lakes, USA," Ecological Applications, vol. 10, no. 4, pp. 1119-1132, 2000.

[10] J. Beguin, D. Pothier, and S. D. Côté, "Deer browsing and soil disturbance induce cascading effects on plant communities: a multilevel path analysis," Ecological Applications, vol. 21, no. 2, pp. 439-451, 2011.

[11] K. A. Bråthen, R. A. Ims, N. G. Yoccoz, P. Fauchald, T. Tveraa, and V. H. Hausner, "Induced shift in ecosystem productivity? Extensive scale effects of abundant large herbivores," Ecosystems, vol. 10, no. 5, pp. 773-789, 2007.

[12] D. A. Wardle, G. M. Barker, G. W. Yeates, K. I. Bonner, and A. Ghani, "Introduced browsing mammals in New Zealand natural forests: aboveground and belowground consequences," Ecological Monographs, vol. 71, no. 4, pp. 587-614, 2001.

[13] N. T. Hobbs, "Large herbivore as sources of disturbance in ecosystems," in Large Herbivore Ecology, Ecosystem Dynamics and Conservation, K. Danell, R. Bergstrom, P. Duncan, and J. Pastor, Eds., pp. 261-288, Cambridge University Press, Cambridge, UK, 2006.

[14] J. K. Bump, C. R. Webster, J. A. Vucetich, R. O. Peterson, J. M. Shields, and M. D. Powers, "Ungulate carcasses perforate ecological filters and create biogeochemical hotspots in forest herbaceous layers allowing trees a competitive advantage," Ecosystems, vol. 12, no. 6, pp. 996-1007, 2009.

[15] W. S. Alverson and D. M. Waller, "Deer populations and the widespread failure of hemlock regeneration in northern forests," in The Science of Overabundance: Deer Ecology and Population Management, W. J. McShea, H. B. Underwood, and J. H. Rappole, Eds., pp. 280-297, Smithsonian Institution Press, Washington, DC, USA, 1997.

[16] Z. T. Long, T. H. Pendergast IV, and W. P. Carson, "The impact of deer on relationships between tree growth and mortality in an old-growth beech-maple forest," Forest Ecology and Management, vol. 252, no. 1-3, pp. 230-238, 2007.

[17] C. S. Holling, "Resilience and stability of ecological systems," Annual Review of Ecology and Systematics, vol. 4, no. 1, pp. 1-23, 1973.

[18] B. Hidding, J.-P. Tremblay, and S. D. Côté, "A large herbivore triggers alternative successional trajectories in the boreal forest," Ecology, vol. 94, no. 12, pp. 2852-2860, 2013.

[19] D. S. deCalesta, "Effect of white-tailed deer on songbirds within managed forests in Pennsylvania," The Journal of Wildlife Management, vol. 58, no. 4, pp. 711-718, 1994.

[20] S. Allombert, A. J. Gaston, and J.-L. Martin, "A natural experiment on the impact of overabundant deer on songbird populations," Biological Conservation, vol. 126, no. 1, pp. 1-13, 2005.

[21] S. Allombert, S. Stockton, and J.-L. Martin, "A natural experiment on the impact of overabundant deer on forest invertebrates," Conservation Biology, vol. 19, no. 6, pp. 1917-1929, 2005.

[22] S. D. Côté, "Impacts on ecosystems," in Biology and Management of White-Tailed Deer, D. G. Hewitt, Ed., pp. 379-398, CRC Press, Boca Raton, Fla, USA, 2011.

[23] T. Nuttle, E. H. Yerger, S. H. Stoleson, and T. E. Ristau, "Legacy of top-down herbivore pressure ricochets back up multiple trophic levels in forest canopies over 30 years," Ecosphere, vol. 2, no. 1, pp. 1-11, 2011.

[24] W. J. McShea and J. H. Rappole, "Managing the abundance and diversity of breeding bird populations through manipulation of deer populations," Conservation Biology, vol. 14, no. 4, pp. 1161$1170,2000$.

[25] R. Smit, J. Bokdam, J. den Ouden, H. Olff, H. Schot-Opschoor, and M. Schrijvers, "Effects of introduction and exclusion of large herbivores on small rodent communities," Plant Ecology, vol. 155, no. 1, pp. 119-127, 2001.

[26] S. D. Côté, "Extirpation of a large black bear population by introduced white-tailed deer," Conservation Biology, vol. 19, no. 5, pp. 1668-1671, 2005.

[27] K. R. Greenwald, L. J. Petit, and T. A. Waite, "Indirect effects of a keystone herbivore elevate local animal diversity," Journal of Wildlife Management, vol. 72, no. 6, pp. 1318-1321, 2008.

[28] S. D. Côté, C. Dussault, J. Huot, F. Potvin, J.-P. Tremblay, and V. Viera, "High herbivore density and boreal forest ecology: white-tailed deer on Anticosti Island," in Lessons from the Islands: Introduced Species and What They Tell Us about How Ecosystems Work, A. J. Gaston, T. E. Golumbia, J.-L. Martin, and S. T. Sharpe, Eds., Proceedings from the Research Group on Introduced Species Conference, Canadian Wildlife Service Occasional Papers, British Columbia, Canada, 2008.

[29] J.-P. Saucier, A. Robitaille, and P. Grondin, "Cadre bioclimatique du Québec," in Manuel de Foresterie, Second Edition, R. Doucet and M. Côté, Eds., Ordre des ingénieurs forestiers du Québec, pp. 186-205, Éditions Multimondes, Québec, Canada, 2009.

[30] M. Barrette, L. Bélanger, and L. De Grandpré, "Preindustrial reconstruction of a perhumid midboreal landscape, Anticosti Island, Quebec," Canadian Journal of Forest Research, vol. 40, no. 5, pp. 928-942, 2010.

[31] S. Parent, M.-J. Simard, H. Morin, and C. Messier, "Establishment and dynamics of the balsam fir seedling bank in old forests of northeastern Quebec," Canadian Journal of Forest Research, vol. 33, no. 4, pp. 597-603, 2003.

[32] B. Rochette and A. Gingras, Inventaire aérien du cerf de Virginie de l'île d'Anticosti-Été 2006, Ministère des Ressources naturelles et de la Faune, Direction de l'aménagement de la faune de la Côte-Nord, Sept-Îles, Canada, 2007. 
[33] A. Massé and S. D. Côté, "Linking alternative food sources to winter habitat selection of herbivores in overbrowsed landscapes," Journal of Wildlife Management, vol. 76, no. 3, pp. 544556, 2012.

[34] M. A. Simard, T. Coulson, A. Gingras, and S. D. Côté, "Influence of density and climate on population dynamics of a large herbivore under harsh environmental conditions," Journal of Wildlife Management, vol. 74, no. 8, pp. 1671-1685, 2010.

[35] F. Potvin, P. Beaupré, and G. Laprise, "The eradication of balsam fir stands by white-tailed deer on Anticosti Island, Québec: a 150-year process," Ecoscience, vol. 10, no. 4, pp. 487-495, 2003.

[36] J.-P. Tremblay, I. Thibault, C. Dussault, J. Huot, and S. D. Côté, "Long-term decline in white-tailed deer browse supply: can lichens and litterfall act as alternative food sources that preclude density-dependent feedbacks," Canadian Journal of Zoology, vol. 83, no. 8, pp. 1087-1096, 2005.

[37] M. Barrette, L. Bélanger, L. De Granpré, and J.-C. Ruel, “Cumulative effects of chronic deer browsing and clear-cutting on regeneration processes in second-growth white spruce stands," Forest Ecology and Management, vol. 329, no. 1, pp. 69-78, 2014.

[38] J. Taillon, D. G. Sauvé, and S. D. Côté, “The effects of decreasing winter diet quality on foraging behavior and life-history traits of white-tailed deer fawns," Journal of Wildlife Management, vol. 70, no. 5, pp. 1445-1454, 2006.

[39] D. G. Sauvé and S. D. Côté, "Winter forage selection in whitetailed deer at high density: balsam fir is the best of a bad choice," Journal of Wildlife Management, vol. 71, no. 3, pp. 911-914, 2007.

[40] J.-P. Tremblay, J. Huot, and F. Potvin, "Density-related effects of deer browsing on the regeneration dynamics of boreal forests," Journal of Applied Ecology, vol. 44, no. 3, pp. 552-562, 2007.

[41] M. Anouk Simard, S. D. Côté, R. B. Weladji, and J. Huot, "Feedback effects of chronic browsing on life-history traits of a large herbivore," Journal of Animal Ecology, vol. 77, no. 4, pp. 678-686, 2008.

[42] P. Beaupré, C. Bédard, C. Dufour, A. Gingras, C. Malenfant, and F. Potvin, Plan général d'aménagement intégré des ressources $d u$ milieu forestier de l'île d'Anticosti, Produits forestiers Anticosti, Québec, Canada, 2004.

[43] J. Huot, F. Potvin, and M. Bélanger, "Southeastern Canada," in White-Tailed Deer Ecology and Management, L. K. Halls, Ed., pp. 293-304, Wildlife Management Institute, Stackpole Books, Harrisburg, Pa, USA, 1984.

[44] F. Reimoser and H. Gossow, "Impact of ungulates on forest vegetation and its dependence on the silvicultural system," Forest Ecology and Management, vol. 88, no. 1-2, pp. 107-119, 1996.

[45] S. Kay, "Factors affecting severity of deer browsing damage within coppiced woodlands in the south of England," Biological Conservation, vol. 63, no. 3, pp. 217-222, 1993.

[46] C. Casabon and D. Pothier, "Browsing of tree regeneration by white-tailed deer in large clearcuts on Anticosti Island, Quebec," Forest Ecology and Management, vol. 253, no. 1-3, pp. 112-119, 2007.

[47] J. W. Hughes and D. A. Bechtel, "Effect of distance from forest edge on regeneration of red spruce and balsam fir in clearcuts," Canadian Journal of Forest Research, vol. 27, no. 12, pp. 20882096, 1997.

[48] D. F. Greene, J. C. Zasada, L. Sirois et al., "A review of the regeneration dynamics of North American boreal forest tree species," Canadian Journal of Forest Research, vol. 29, no. 6, pp. 824-839, 1999.
[49] J. Beguin, D. Pothier, and M. Prévost, "Can the impact of deer browsing on tree regeneration be mitigated by shelterwood cutting and strip clearcutting?" Forest Ecology and Management, vol. 257, no. 1, pp. 38-45, 2009.

[50] J. Beguin, M. Prévost, D. Pothier, and S. D. Côté, "Establishment of natural regeneration under severe browsing pressure from white-tailed deer after group seed-tree cutting with scarification on Anticosti Island," Canadian Journal of Forest Research, vol. 39, no. 3, pp. 596-605, 2009.

[51] P. Feeny, "Plant apparency and chemical defense," in Biochemical Interactions between Plants and Insects, J. W. Wallace and R. L. Mansell, Eds., vol. 10 of Recent Advances in Phytochemistry, pp. 1-40, Plenum Press, New York, NY, USA, 1976.

[52] A. M. Miller, C. McArthur, and P. J. Smethurst, "Characteristics of tree seedlings and neighbouring vegetation have an additive influence on browsing by generalist herbivores," Forest Ecology and Management, vol. 228, no. 1-3, pp. 197-205, 2006.

[53] J. Faure-Lacroix, J.-P. Tremblay, N. Thiffault, and V. Roy, "Stock type performance in addressing top-down and bottom-up factors for the restoration of indigenous trees," Forest Ecology and Management, vol. 307, pp. 333-340, 2013.

[54] A. J. Hester, L. Edenius, R. M. Buttenschøn, and A. T. Kuiters, "Interactions between forests and herbivores: the role of controlled grazing experiments," Forestry, vol. 73, no. 4, pp. 381-391, 2000.

[55] R. J. Fuller and R. M. A. Gill, "Ecological impacts of increasing numbers of deer in British woodland," Forestry, vol. 74, no. 3, pp. 193-199, 2001.

[56] R. Bergström and L. Edenius, "From twigs to landscapesmethods for studying ecological effects of forest ungulates," Journal for Nature Conservation, vol. 10, no. 4, pp. 203-211, 2003.

[57] T. P. Rooney and D. M. Waller, "Direct and indirect effects of white-tailed deer in forest ecosystems," Forest Ecology and Management, vol. 181, no. 1-2, pp. 165-176, 2003.

[58] J.-P. Tremblay, J. Huot, and F. Potvin, “Divergent nonlinear responses of the boreal forest field layer along an experimental gradient of deer densities," Oecologia, vol. 150, no. 1, pp. 78-88, 2006.

[59] A. A. Royo and W. P. Carson, "On the formation of dense understory layers in forests worldwide: consequences and implications for forest dynamics, biodiversity, and succession," Canadian Journal of Forest Research, vol. 36, no. 6, pp. 13451362, 2006.

[60] M. Bachand, S. Pellerin, M. Moretti et al., "Functional responses and resilience of boreal forest ecosystem after reduction of deer density," PLoS ONE, vol. 9, no. 2, Article ID e90437, 2014.

[61] B. Hidding, J.-P. Tremblay, and S. D. Côté, "Survival and growth of balsam fir seedlings and saplings under multiple controlled ungulate densities," Forest Ecology and Management, vol. 276, pp. 96-103, 2012.

[62] K. N. Suding, K. L. Gross, and G. R. Houseman, "Alternative states and positive feedbacks in restoration ecology," Trends in Ecology and Evolution, vol. 19, no. 1, pp. 46-53, 2004.

[63] K. Cuddington, "Legacy effects: the persistent impact of ecological interactions," Biological Theory, vol. 6, no. 3, pp. 203-210, 2012.

[64] A. J. Tanentzap, D. R. Bazely, S. Koh et al., "Seeing the forest for the deer: do reductions in deer-disturbance lead to forest recovery?" Biological Conservation, vol. 144, no. 1, pp. 376-382, 2011. 
[65] A. A. Royo, R. Collins, M. B. Adams, C. Kirschbaum, and W. P. Carson, "Pervasive interactions between ungulate browsers and disturbance regimes promote temperate forest herbaceous diversity," Ecology, vol. 91, no. 1, pp. 93-105, 2010.

[66] D. P. J. Kuijper, B. Jedrzejewska, B. Brzeziecki, W. Jędrzejewski, and H. Żybura, "Fluctuating ungulate density shapes tree recruitment in natural stands of the Białowieza Primeval Forest, Poland," Journal of Vegetation Science, vol. 21, no. 6, pp. 10821098, 2010.

[67] J. P. Rosenthal and P. M. Kotanen, "Terrestrial plant tolerance to herbivory," Trends in Ecology and Evolution, vol. 9, no. 4, pp. 145-148, 1994.

[68] F. Lebel, C. Dussault, A. Massé, and S. D. Côté, "Influence of habitat features and hunter behavior on white-tailed deer harvest," Journal of Wildlife Management, vol. 76, no. 7, pp. 14311440, 2012.

[69] M.-A. Simard, J. Huot, S. de Bellefeuille, and S. D. Côté, "Influences of habitat composition, plant phenology, and population density on autumn indices of body condition in a northern white-tailed deer population," Wildlife Monographs, vol. 187, no. 1, pp. 1-28, 2014.

[70] W. F. Porter, N. E. Mathews, H. B. Underwood, R. W. Sage Jr., and D. F. Behrend, "Social organization in deer: implications for localized management," Environmental Management, vol. 15, no. 6, pp. 809-814, 1991.

[71] S. A. McNulty, W. F. Porter, N. E. Mathews, and J. A. Hill, "Localized management for reducing white-tailed deer populations," Wildlife Society Bulletin, vol. 25, no. 2, pp. 265-271, 1997.

[72] M. A. Simard, C. Dussault, J. Huot, and S. D. Côté, "Is hunting an effective tool to control overabundant deer? A test using an experimental approach," Journal of Wildlife Management, vol. 77, no. 2, pp. 254-269, 2013.

[73] S. E. Van Wieren, "Effects of large herbivores upon the animal community," in Grazing and Conservation Management, M. F. W. DeVries, J. P. Bakker, and S. E. Van Wieren, Eds., pp. 185214, Kluwer Academic, Boston, Mass, USA, 1998.

[74] O. Suominen and O. K. Danell, "Effects of large herbivores on other fauna," in Large Herbivore Ecology, Ecosystem Dynamics And Conservation, K. Danell, R. Bergstrom, P. Duncan, and J. Pastor, Eds., pp. 383-412, Cambridge University Press, Cambridge, UK, 2006.

[75] K. M. Mathisen and C. Skarpe, "Cascading effects of moose (Alces alces) management on birds," Ecological Research, vol. 26, no. 3, pp. 563-574, 2011.

[76] C. N. Foster, P. S. Barton, and D. B. Lindenmayer, "Effects of large native herbivores on other animals," Journal of Applied Ecology, vol. 51, no. 4, pp. 929-938, 2014.

[77] E. Cardinal, J.-L. Martin, J.-P. Tremblay, and S. D. Côté, "An experimental study of how variation in deer density affects vegetation and songbird assemblages of recently harvested boreal forests," Canadian Journal of Zoology, vol. 90, no. 6, pp. 704-713, 2012.

[78] E. Cardinal, J.-L. Martin, and S. D. Côté, "Large herbivore effects on songbirds in boreal forests: lessons from deer introduction on anticosti Island," Ecoscience, vol. 19, no. 1, pp. 38-47, 2012.

[79] P.-M. Brousseau, C. Hébert, C. Cloutier, and S. D. Côté, "Short-term effects of reduced white-tailed deer density on insect communities in a strongly overbrowsed boreal forest ecosystem," Biodiversity and Conservation, vol. 22, no. 1, pp. 7792, 2013.
[80] G. Darmon, B. Hidding, S. De Bellefeuille, J.-P. Tremblay, and S. D. Côté, "A generalist rodent benefits from logging regardless of deer density," Ecoscience, vol. 20, no. 4, pp. 319-327, 2014.

[81] M. Scheffer and S. R. Carpenter, "Catastrophic regime shifts in ecosystems: linking theory to observation," Trends in Ecology and Evolution, vol. 18, no. 12, pp. 648-656, 2003.

[82] T. Nuttle, A. A. Royo, M. B. Adams, and W. P. Carson, "Historic disturbance regimes promote tree diversity only under low browsing regimes in eastern deciduous forest," Ecological Monographs, vol. 83, no. 1, pp. 3-17, 2013.

[83] T. Nuttle, T. E. Ristau, and A. A. Royo, "Long-term biological legacies of herbivore density in a landscape-scale experiment: forest understoreys reflect past deer density treatments for at least 20 years," Journal of Ecology, vol. 102, no. 1, pp. 221-228, 2014.

[84] J. Pastor, B. Dewey, R. J. Naiman, P. F. McInnes, and Y. Cohen, "Moose browsing and soil fertility in the boreal forests of Isle Royale National Park," Ecology, vol. 74, no. 2, pp. 467-480, 1993.

[85] J. O. Tahvanainen and R. B. Root, "The influence of vegetational diversity on the population ecology of a specialized herbivore, Phyllotreta cruciferae (Coleoptera: Chrysomelidae)," Oecologia, vol. 10, no. 4, pp. 321-346, 1972.

[86] C. D. Thomas, "Butterfly larvae reduce host plant survival in vicinity of alternative host species," Oecologia, vol. 70, no. 1, pp. 113-117, 1986.

[87] P. Barbosa, J. Hines, I. Kaplan, H. Martinson, A. Szczepaniec, and Z. Szendrei, "Associational resistance and associational susceptibility: having right or wrong neighbors," Annual Review of Ecology, Evolution, and Systematics, vol. 40, no. 1, pp. 1-20, 2009.

[88] M. Bachand, S. Pellerin, S. D. Côté et al., "Species indicators of ecosystem recovery after reducing large herbivore density: comparing taxa and testing species combinations," Ecological Indicators, vol. 38, no. 1, pp. 12-19, 2014.

[89] J. Hjältén, K. Danell, and L. Ericson, "Effects of simulated herbivory and intraspecific competition on the compensatory ability of birches," Ecology, vol. 74, no. 4, pp. 1136-1142, 1993.

[90] R. A. Riggs, A. R. Tiedemann, J. G. Cook et al., "Modification of mixed-conifer forests by ruminant herbivores in the Blue Mountains Ecological Province," Research Paper PNW-RP-527, USDA Forest Service, Portland, Ore, USA, 2000.

[91] I.-L. Persson, K. Danell, and R. Bergström, "Different moose densities and accompanied changes in tree morphology and browse production," Ecological Applications, vol. 15, no. 4, pp. 1296-1305, 2005.

[92] N. G. Tilghman, "Impacts of white-tailed deer on forest regeneration in Northwestern Pennsylvania," Journal of Wildlife Management, vol. 53, no. 3, pp. 524-532, 1989.

[93] S. B. Horsley, S. L. Stout, and D. S. deCalesta, "White-tailed deer impact on the vegetation dynamics of a northern hardwood forest," Ecological Applications, vol. 13, no. 1, pp. 98-118, 2003.

[94] J. Olofsson, H. Kitti, P. Rautiainen, S. Stark, and L. Oksanen, "Effects of summer grazing by reindeer on composition of vegetation, productivity and nitrogen cycling," Ecography, vol. 24, no. 1, pp. 13-24, 2001.

[95] M. Manseau, J. Huot, and M. Crête, "Effects of summer grazing by caribou on composition and productivity of vegetation: community and landscape level," Journal of Ecology, vol. 84, no. 4, pp. 503-513, 1996.

[96] J. Moen and A. Lagerström, "High species turnover and decreasing plant species richness on mountain summits in 
Sweden: reindeer grazing overrides climate change?" Arctic, Antarctic, and Alpine Research, vol. 40, no. 2, pp. 382-395, 2008.

[97] R. E. Longton, The Biology of Polar Bryophytes and Lichens, Cambridge University Press, Cambridge, UK, 1988.

[98] A. R. E. Sinclair and P. Arcese, Eds., Serengeti II: Dynamics, Management, and Conservation of an Ecosystem, University of Chicago Press, Chicago, Ill, USA, 1995.

[99] G. P. Asner, S. R. Levick, T. Kennedy-Bowdoin et al., "Largescale impacts of herbivores on the structural diversity of African savannas," Proceedings of the National Academy of Sciences of the United States of America, vol. 106, no. 12, pp. 4947-4952, 2009.

[100] S. C. F. Palmer, A. J. Hester, D. A. Elston, I. J. Gordon, and S. E. Hartley, "The perils of having tasty neighbors: grazing impacts of large herbivores at vegetation boundaries," Ecology, vol. 84, no. 11, pp. 2877-2890, 2003.

[101] K. Boege and R. J. Marquis, "Facing herbivory as you grow up: the ontogeny of resistance in plants," Trends in Ecology and Evolution, vol. 20, no. 8, pp. 441-448, 2005.

[102] J. Bergquist and G. Örlander, "Browsing damage by roe deer on Norway spruce seedlings planted on clearcuts of different ages: 1. Effect of slash removal, vegetation development, and roe deer density," Forest Ecology and Management, vol. 105, no. 1-3, pp. 283-293, 1998.

[103] J. Bergquist and G. Örlander, "Browsing damage by roe deer on Norway spruce seedlings planted on clearcuts of different ages, 2: Effect of seedling vigour," Forest Ecology and Management, vol. 105, no. 1-3, pp. 295-302, 1998.

[104] M. Dufresne, R. L. Bradley, J.-P. Tremblay, and S. D. Côté, "Evidence that soil depth and clay content control the postdisturbance regeneration of balsam fir and paper birch under heavy browsing from deer," Ecoscience, vol. 18, no. 4, pp. 363368, 2011.

[105] R. M. A. Gill, "A review of damage by mammals in north temperate forests: 3. Impact on trees and forests," Forestry, vol. 65, no. 4, pp. 363-388, 1992.

[106] B. M. Roche and R. S. Fritz, "Genetics of resistance of Salix sericea to a diverse community of herbivores," Evolution, vol. 51, no. 5, pp. 1490-1498, 1997.

[107] M. Rousi, J. Tahvanainen, H. Henttonen, D. A. Herms, and I. Uotila, "Clonal variation in susceptibility of white birches (Betula spp.) to Mammalian and insect herbivores," Forest Science, vol. 43, no. 3, pp. 396-402, 1997.

[108] G. Vourc'h, B. Vila, D. Gillon et al., "Disentangling the causes of damage variation by deer browsing on young Thuja plicata," Oikos, vol. 98, no. 2, pp. 271-283, 2002. 

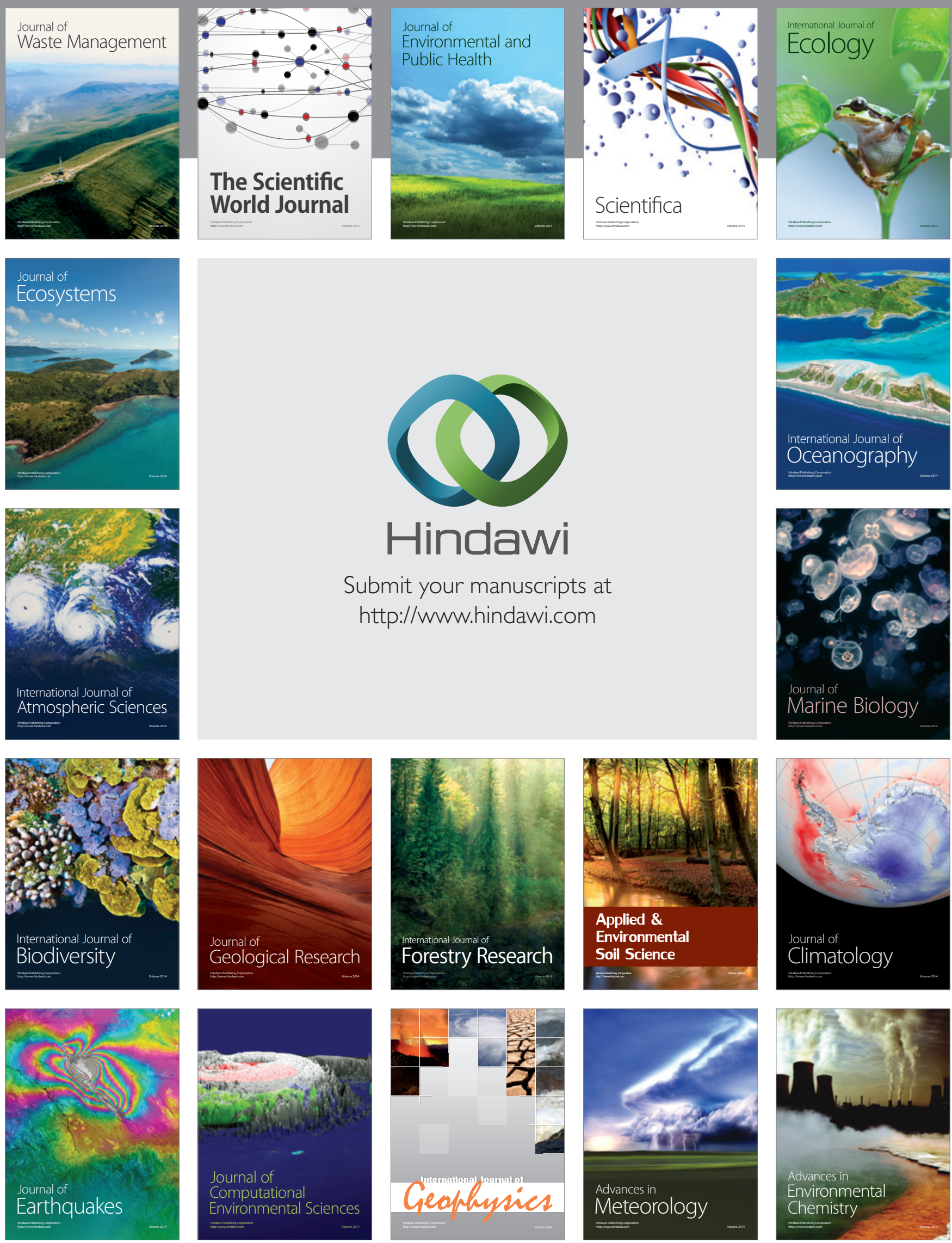